\title{
TANULÁSTÁMOGATÁS A FELSŐOKTATÁSBAN ONLINE MENTORÁLÁSI KÉZIKÖNYV (RECENZIÓ)
}

A recenzió szerzője:

Kovács-Veréb Lilla

Eszterházy Károly Egyetem

\section{Lektorok:}

Bognárné dr. Kocsis Judit Pannon Egyetem

Lehoczky Mária Magdolna Károli Gáspár Református Egyetem

Szerző e-mail címe: vereb.lilla@gmail.com ...és további két anonim lektor

Kovács-Veréb Lilla (2020): Tanulástámogatás a felsőoktatásban online mentorálási kézikönyv (Recenzió). OxIPO - interdiszciplináris tudományos folyóirat, 2020/1, 113-116. doi: 10.35405/OXIPO.2020.1.113

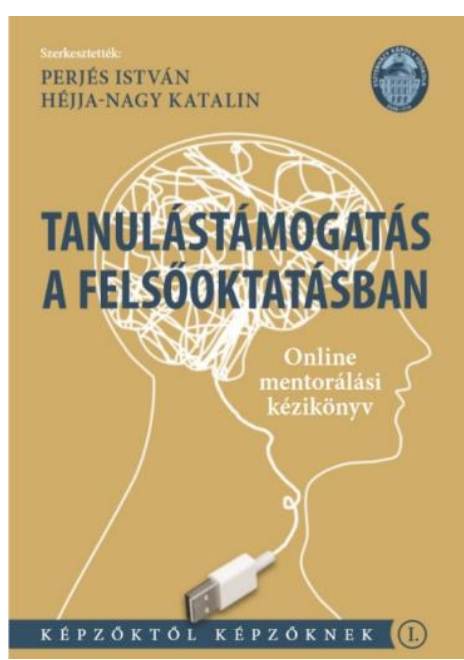


Ajánlom ezt a művet minden olyan érdeklődő olvasónak - főként pedagógusképzésben részt-vevő oktatónak és hallgatónak -, aki szeretne minél több ismeretet szerezni a mentorálásról mint tevékenységről, valamint komplex képet kíván kapni a mentor ezen tevékenységéhez szükséges képességeinek fejlesztéséről és a mentorált motivációinak támogatásáról egyaránt.

A „Tanulástámogatás a felsőoktatásban. Online mentorálási kézikönyv" 2015-ben jelent meg a „MeMOOC angol és magyar nyelvű on-line képzési központ létrehozása és üzemeltetése" című Támop 4.1.2.F15/1-2015-0001 pályázat támogatásával, az egri Eszterházy Károly Egyetem gondozásában. A szerkesztők: Perjés István és Héjja-Nagy Katalin. A szerzők: Taskó Tünde Anna, Hülber László, Mogyorósi Zsolt, Virág Irén, Dávid Mária, Simándi Szilvia, Hatvani Andrea, Héjja-Nagy Katalin, illetve Faragó Boglárka. A bevezető gondolatokat Ollé János írta.

A téma aktualitását az adja, hogy napjainkban a digitális kompetencia nélkülözhetetlen az egyén legkülönfélébb tevékenységeiben, így a tanulás, valamint a munkavégzés során is. A felsőoktatásban több olyan képzés kerül látókörünkbe, melyhez digitális tananyagok készülnek és/vagy kapcsolódik a képzéshez online tanulási környezet is. Amennyiben ez intézményi szinten esetlegesen még nem szerveződött meg, és/vagy a tanulók jellemzően kialakítják saját online társas környezetüket, azokon a helyeken informális keretek között (például közösségi oldalak csoportjaival, vagy levelezőlisták létrehozásával), az információ megosztás útján növelni tudják képzésük hatékonyságát. Nagy jelentőséggel bír a mű, hiszen segíthet a tudatos, hatékony online tanulási környezet kialakításának, s értelmezési keretet nyújt korunk pedagógusainak a professzionális tanulástámogatásban, különösen a felsôoktatás területén.

A bevezetés szerzője a digitális tananyagok fejlesztése és az online tanulási környezet kialakítása mentén megerősíti, hogy a pedagógusok jelenléte kulcsfontosságú a tanulási folyamat szabályozása kapcsán. Előnyök és hátrányok említésével segíti értelmezni az online képzések témakörét, s megállapítja, hogy - mint más területeken - ezen a színtéren is a cél a minőségi oktatásra való törekvés. A minőségi oktatás egyik alappillére az oktató személye, a mentor, akinek feladata az önszabályozó tanulás támogatása, természetesen a tanulói sajátosságokat, egyéni attribútumokat figyelembe véve.

A mû három nagy egységre osztható: az első fejezet a mentorálás megközelítéseiről szól, majd a kézikönyv széleskörű szakirodalmi áttekintése kiterjed a mentor és a mentorált személyére is. Részletesen taglalja a második fejezetben a mentoráláshoz szükséges képességek fejlesztésének lehetőségét, ugyanakkor a harmadik fejezetben ismerteti a mentorált motivációinak sokoldalú támogatását/támogatási lehetőségeit. 
Az első fejezetben a mentor kifejezés fogalma, annak feladatai és szerepe kerül áttekintésre, majd az online mentorálás, ementorálás, cybermentorálás, virtuális mentorálás, elektronikus mentorálás céljait, erényeit és nehézségeit, valamint a szereplők feladatait taglalják, egészen a sikeres alkalmazás feltételeinek ismertetéséig. Ezt követően a mû az online mentorálás gyakorlatával foglalkozik, áttekinti az online térben történő interakciós tevékenységek elméleti hátterét és kapcsolódó kutatási eredményeket egyaránt, továbbá a különböző oktatói tevékenységtípusokhoz illeszthető mentori munkát részletezi. Az első fejezet zárásaként a mentorálást segítő dokumentumokba tekinthetünk be, melyek segítik a tervezést, a nyomon követést és természetesen az értékelést is.

A második fejezet a pedagógiai kommunikáció jellemzőit, színtereit, valamint a hatékony és a nem hatékony pedagógiai kommunikációt mutatja be a kézikönyv. Ezt követően a pedagóguskutatásokról olvashatunk, illetve a kommunikációs készségek fontosságáról a mentorálás folyamatában. Későbbiekben a reflektivitás pedagógiai értelmezése és fogalmi megközelítése, valamint annak gyakorlata kerül bemutatásra. Foglalkozik a kézikönyv a reflektív tanárral és tanítással, és magával a reflektív gondolkodás fejlesztésével is, mellyel hozzájárulni kívánnak a gyakorlatra történő felkészüléshez. A következő alfejezetben a felsőoktatásban történő értékelés témakörét járja körbe a mű, melyben kitér a fejlesztő értékelés fogalmára és lehetőségeire. Megállapítják, hogy a fejlesztő értékelés hozzájárulhat a hallgatók tanulási eredményességének növeléséhez, melynek segítségével megismerésre kerülhetnek az értékelés fogalmi megközelítései, funkciói és annak folyamata. A második fejezet kitér még a tanulási hatékonyság támogatására az online felsőoktatási környezetben. Értelmezi az irányított önálló tanulás és az önszabályozott tanulás viszonyát, valamint tanulásmódszertani ajánlásokat is kap az olvasó. Ezt követően megerősítik az önreflexió fontosságát a tanulásfejlesztés területén, majd végül a mentorok tanulástámogató feladataira tér ki a fejezet.

A harmadik fejezetben a felnőttkori tanulást a felsőoktatásban, a fiatal felnőtt hallgatók szemszögéből közelítik meg. Betekintést nyerhetünk a mű által a fiatal felnőttkor értelmezéseibe, ezen célcsoport tanulását segítő és hátráltató elemeibe. A hallgató érdeklődése a tanulás sikerességét is befolyásolja, ezért megismerjük a fejezetből a tanulás motivációs alapjait, valamint a motivációt befolyásoló külső és belső tényezőket: alapfogalmakat, elméleteket és gyakorlati tanácsokat is. A szerzők a harmadik fejezet további részében a hallgatók online környezetben történő motiválását veszik górcső alá, okokat keresnek a lemorzsolódásra, majd a különböző tapasztalatokkal bíró hallgatók tanulási motívumait mutatják be.

A szerzők a könyvet egy rövid összegzéssel zárják, ahol megerősítik az oktatási 
céllal készült játékok motiváló hatását az online tanulási környezetben is. A mű végén találhatjuk meg a szövegközi ábrák és táblák jegyzékét, valamint a mellékleteket.

Összefoglalva a mû kellő alapossággal járja körbe a mentorálás témakörét. Ezt a tényt támasztja alá a kézikönyv szakirodalmi jegyzéke is, ahol közel 15 oldalon át tartó, több mint 200 hazai és külföldi szakirodalmat vonultatnak fel a szerzők.
A kézikönyv erénye, hogy az egyes fejezetek végén feladatokat ad az olvasó számára, aki ezáltal ellenőrizheti, hogy az olvasott ismereteket milyen mértékben sikerült elsajátítania; azzal párhuzamba állítva ezt, ahogyan a szerzők több fejezetben is kitérnek az ellenőrzés, önellenőrzés fontosságára és szükségességére az online tanulási környezetben (is). 